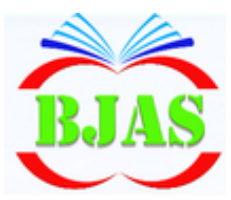

ISSN 1814 - 5868
Available online at $\mathrm{http}: / /$ bajas.edu.iq

College of Agriculture, University of Basrah

DOi:10.21276/basjas

\title{
Effect of Endosulfan Pesticide on the Oxygen Consumption Rate of Three Species of Snails Collected from Middle Part of Shatt Al-Arab River
}

\author{
Aseel N. Al-Salman ${ }^{1 *}$; Wisam A.A. Farid ${ }^{2} \&$ Wasan A. A. Ali ${ }^{2}$ \\ ${ }^{1}$ Department of Pathology and Poultry, College of Veterinary Medicine, University of \\ Basrah \\ ${ }^{2}$ Department of Community Health Technology, College of Health and Medical \\ Technology in Basrah, Southern Technical University \\ *Corresponding author e-mail: aseelnk79@gmail.com
}

Received 26 March 2019; Accepted 10 July 2019; Available online 3 November 2019

\begin{abstract}
The present study has been achieved to estimate the acute toxicity effect of pesticide (endosulfan) (organochlorine) and its sublethal concentrations effect on the oxygen consuming rate of three various snails species (Melanoides tuberculata, Radix auricularia and Theodoxus jordani) collected from Shatt Al-Arab river along the region extended from Abu-Al-Khasib to Garmat-Ali during 2018. The $24 \mathrm{hr} \mathrm{LC} \mathrm{L}_{50}$ indicated that the $M$. tuberculata was more resistant, while $R$. auricularia and $T$. jordani were more effective to endosulfan and showed no difference. The study indicated that the employ of various species of snails, with their differing degree of sensitivity to the same toxicant, might be a useful tool in aquatic environmental toxicological investigations. The sublethal concentrations exposure $\left(24 \mathrm{hr} \mathrm{LC}_{50}\right)$ of pesticide had no considerable influence on the rates of oxygen consumption for each snail species. However, a decrease in the capability of snails to preserve respiratory independence through hypoxia was observed $24 \mathrm{hr}$ after exposure to this dose.
\end{abstract}

Keywords: Pesticide, Snails, Shatt Al-Arab river, Acute toxicity, LC $_{50}$

\section{Introduction}

Important data exists about the sensibility of aquatic organisms like fishes, crustaceans, and mollusks toward pesticides and their impacts on various physiological factors from around the world (Hose \& Van den Brink, 2004; Schafer et al., 2007; Archambault \& Cope, 2016; Finnegan et al., 2017). However, comparatively few data have been found on the bioassays accomplished with Shatt AlArab river species in general and on snails in particular. Many species of snails are found in the Shatt Al-Arab river, and due to the biophysiological differences among these species (Farid, 2007), different snail species are likely to have different sensitivities to toxic substances.

Respiration is an important phenomenon of life and the rate of oxygen consumption reflects the internal metabolic activities of animals (Jadhav et al., 2012). In aquatic 
Al-Salman et al. / Basrah J. Agric. Sci., 32 (Special Issue): 323-331, 2019

animals, respiration plays a major role in controlling the conversion of energy. Therefore, the metabolic responses of organisms due to changes in the surrounding environment refer to the adaptive capacity of the organism (Zimmer et al., 2014; Alexis et al., 2017). The increase in population leads to pollution of the environment that reduces the oxygen available in the water media. Agricultural, industrial and domestic effluents lead to degradation of aquatic organisms (Mateo-Sagasta \& Burke, 2010; Bhuiyan et al., 2013; Ahmed et al., 2015). Environmental pollution from pesticides is an important issue that attracts wide public attention. Among them, organophosphate and organochlorine pesticides are routinely used in agriculture (Schreinemachers \& Tipraqsa, 2012). It has been shown that respiration in the presence of the pesticide through gills will be rapid in aquatic animals at high temperature, because the demand for oxygen increases during low solubility (Mane et al., 2012). Several studies have been conducted on this subject (Kamble \& Shinde, 2012; Mane et al., 2012; Burridge, 2013; Xu \& Liu, 2014). Respiration is a vital process in which organisms obtained and used energy through oxidative metabolism. Aquatic animals have to pass large quantities of water over their respiratory surface when they are relatively exposed to high risk of toxic substances (Burridge, 2013). Considering this point of view, the aim of current study was conducted; (ii) to investigate whether different species of Shatt Al-Arab river snails could exhibit differences in sensitiveness to organochlorine pesticide (endosulfan). (ii) to determine the impact of endosulfan sublethal concentration on the snails oxygen consumption.

\section{Materials and Methods}

Adult and uniform size snails, Melanoides tuberculata (Müller), Theodoxus jordani (Soweby) and Radix auricularia (Linneus) were collected from middle part of Shatt AlArab river along the region extended from Abu-Al-Khasib to Garmat-Ali during 2018 for bioassys. Specimens were relocated to the fish laboratory of Veterinary Medicine College, University of Basrah at $20 \pm 1{ }^{\circ} \mathrm{C}$ under aerated conditions and $12 \mathrm{hr}: 12 \mathrm{hr}$ light/dark cycle. The ventilation was stopped after acclimation for $24 \mathrm{hr}$.

Natural river water collected from the Shatt Al-Arab river was utilized to prepare dilutions in the biological experiments, where the water was filtered (through $0.45 \mu \mathrm{m}$ Whatman sterile membrane filter) and boiled (to kill the microorganisms) prior to use. The quality parameters of the control/dilution river water fixed in the experiments during the test period are 6.8-6.9 mg. $\mathrm{l}^{-1}$ (dissolved oxygen), 7.5-7.9 (pH), 23.3-27.5 ${ }^{\circ} \mathrm{C}$ (temperature), 5.1$5.3 \%$ (salinity), and 1155-1187 $\mu$ mos $\mathrm{cm}^{-1}$ (conductivity).

The mortality rate was determined within $24 \mathrm{hr}$ of exposure to endosulfan using the method developed by the USEPA (2002) with some modifications (in size of containers, types of organisms and pesticide). Glass containers $\left(10 \times 7 \times 20 \mathrm{~cm}^{3}\right)$ were utilized for tests. Endosulfan stock solution (95\% purity, Hindustan Insecticides Limited, India) was prepared using acetone as a solvent and a dilution agent to make up a stock solution of endosulfan concentration at $40 \mathrm{~g} \mathrm{~L}^{-1}$. The stock solution is placed in chiller at $4{ }^{\circ} \mathrm{C}$. After initial testing, the concentration range from 0-20 mg. $\mathrm{l}^{-1}$ was chosen for toxicity tests. In volumetric flasks, different concentrations $\left(2,5,10,15\right.$, and $\left.20 \mathrm{mg} . \mathrm{l}^{-1}\right)$ of pesticide were prepared utilizing natural river water and 


\section{Al-Salman et al. / Basrah J. Agric. Sci., 32 (Special Issue): 323-331, 2019}

suitable amounts of stock solution. Each test was achieved with five different concentrations of endosulfan as well as a control consisting the same acetone quantity such as in the highest pesticide concentration used. Each glass container is loaded with $1 \mathrm{~L}$ of proper concentration of pesticide. Three replicated containers consisting 10 snails were employed for each concentration. The last line was let go as intermediate transport containers to avert dilution of the pesticide solutions in experimental containers when snails were exposed. Three containers were utilized for each species of snails filled and covered with a glass lid. Snails weren't fed through tests. Mortality of snails were registered if no response was detected and dead animals were removed when found. $\mathrm{LC}_{50}$ values and confidence limits 95\% were estimated by plotted the percentage of dead snails after 24 hours of exposure against the concentrations of pesticides according the method of Huang (2001).

Before measuring the oxygen consumption rates, a set of each studied snail was subjected to pesticide concentration (sublethal) of $24 \mathrm{hr}$ $\mathrm{LC}_{50}$ at $25 \pm 1^{\circ} \mathrm{C}$ for $24 \mathrm{hr}$ through which they didn't eat. Other set of snails of each species were employed as control treatment and preserved in the same experiential conditions in clean Shatt Al-Arab river water and in clean river water consisting acetone at a concentration similar to that found in the experiential assay. The influences of pesticide exposition and oxygen tenseness on the oxygen consuming rates of various snails species were established using Gilson differential respirometer (Gilson Medical Electronics, Wisconsin, USA).

Prior being transmitted to the flasks, the snails were washed again with clean river water at the proper salinity to assure that the contamination of bacteria was in low state. The snails (three individuals) were placed in a chain of $100 \mathrm{ml}$ flasks and then placed in the test temperature to thirty min through that period the flasks were constantly shaken at a speed of forty-five vibrations in min. Control treatment that doesn't contain snails is utilized of each test run. After equilibration, oxygen consuming was estimated each thirty to forty-five min at two to four hours period. After the finish of each test, the snails were isolated form flasks and the lengths of the snails total body were measured by the ruler. The flasks were washed with concentrated cleaner (PCC/54) (USA) to reduce bacterial pollution.

The oxygen consumption rates of snails was estimated at the acclimatization temperature of $20^{\circ} \mathrm{C}$. The rates of oxygen consuming were estimated from list traces of ten Torr in oxygen tenseness $\left(\mathrm{Po}_{2}\right)$ periods after fling from the oxygen consumption rate mean of water obtained from control runs.

The oxygen consumption weight specific rates $\left(\mathrm{Mo}_{2}\right)$ in normoxic statuses were determine from the $\mathrm{Po}_{2}$ changes chart traces at time (100 Torr) via dividing the oxygen consuming (total) of each snails set by the individuals number in the volumetric flask and through their dry weight mean. The dry weight (total) of snails in each flask was taken follow oven drying in $24 \mathrm{hr}$ at $60^{\circ} \mathrm{C}$. Finally, the oxygen consumption weight specific rates were explicated as $\mu \mathrm{mol} \mathrm{O}_{2} \mathrm{mg}^{-1} \mathrm{~h}^{-1}\left(\mathrm{Mo}_{2}\right)$ (Varó et al., 1993).

One way ANOVA and the test of Tukey's multiple range $(p \leq 0.05)$ were used to compared the $\mathrm{LC}_{50}$ values. The data of oxygen consumption obtained from subjected the snails to pesticide concentrations (sublethal) ( $\left.24 \mathrm{hr} \mathrm{LC}_{50}\right)$ were compared by Two 
way ANOVA. The analysis factors were species and treatment (Bruce \& Bruce, 2017).

\section{Results}

Fig. (1) represents the $24 \mathrm{hr} \mathrm{LC}_{50}$ mean values of pesticide endosulfan for three species of snails studied. The mean $24 \mathrm{hr} \mathrm{LC}_{50}$ values were 4.23, 7.64 and $3.98 \mathrm{mg} . \mathrm{l}^{-1}$ for $T$. jordani, $M$. tuberculata and $R$. auricularia respectively. One way ANOVA analysis method exhibited that there were statistically significant differences $(\mathrm{p} \leq 0.05)$ among snail species were exist. The analysis by Tukey's multiple range test showed that $M$. tuberculata was the most resistant to pesticide. No statistically significant differences $(p>0.05)$ in the $\mathrm{LC}_{50}$ values of other snails species ( $T$. jordani and R.auricularia) were found.

Exposure of snails species to $24 \mathrm{hr} \mathrm{LC}_{50}$ effected on the relation between $\mathrm{Mo}_{2}$ and $\mathrm{Po}_{2}$

(Fig. 2). It was noted that the capacity of all species of snails to preserve their $\mathrm{Mo}_{2}$ nearly stable over a broad range of $\mathrm{Po}_{2}$ reduced while they were subjected to pesticide. The critical of $\mathrm{Po}_{2}(\mathrm{Pc})$ values (in which the independence of respiratory can't be preserved for a long time)are registered of three species of snails that were in the range of 40-60 Torr to control treatment and treatment of control with acetone sets. However, the Pc excesses of 60-80 Torr when each snail species was subjected to pesticide.

Values of $\mathrm{Mo}_{2}$ of each snail species and each treatment in normoxic statuses are shown in Fig. (3). The analysis of two-way ANOVA showed no statistically significant differences $(p>0.05)$ were exist for $\mathrm{Mo}_{2}$ for snails at each treatment used (to the same species or to the various species of snails that have been studied).

\section{Discussion}

Three different species of snails from the Shatt Al-Arab river have a different sensibility to organochlorine endosulfan pesticide. The values of $24 \mathrm{hr} \mathrm{LC}_{50}$ showed that $M$. tuberculata was the most resistant to the pesticide, while $T$. jordani and $R$. auricularia were lower tolerant. No statistically significant differences in the values of $24 \mathrm{hr} \mathrm{LC}_{50}$ calculated of $T$. jordani and $R$. auricularia were found.

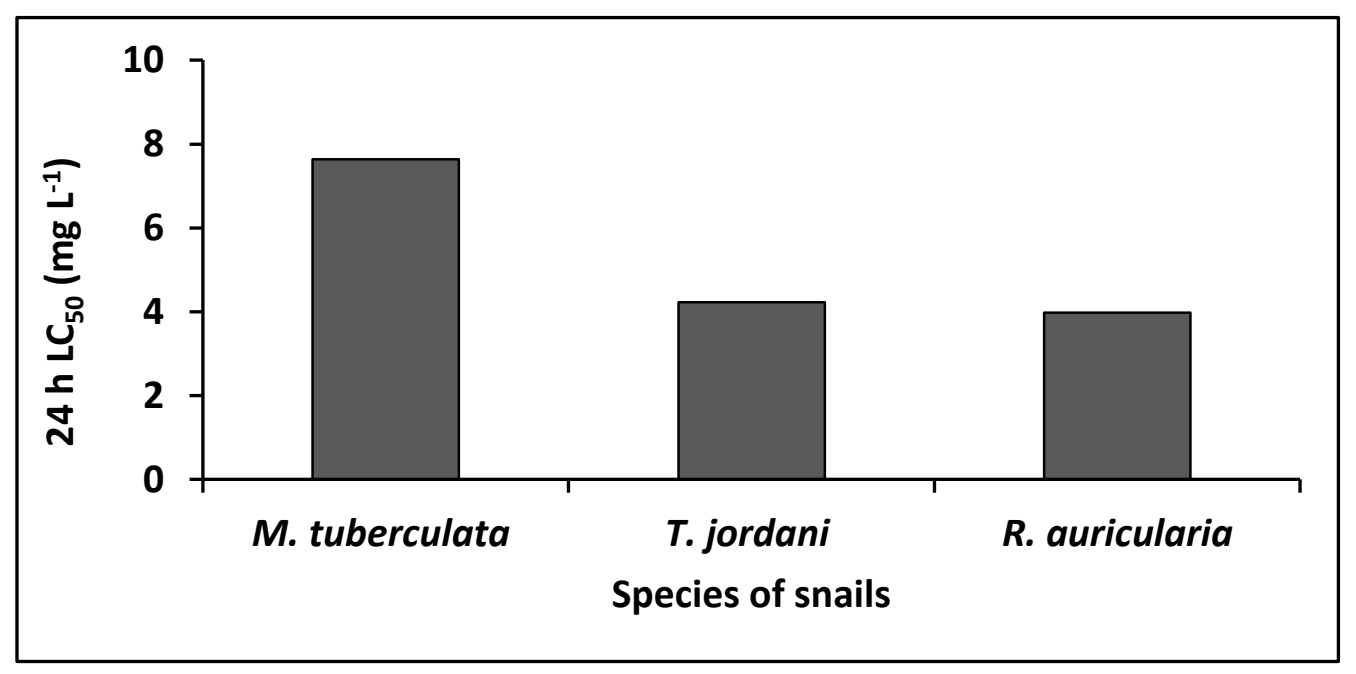

Fig. (1): The mean values of $24 \mathrm{~h} \mathrm{LC} 50$ of Shatt Al-Arab river snails. 
Al-Salman et al. / Basrah J. Agric. Sci., 32 (Special Issue): 323-331, 2019

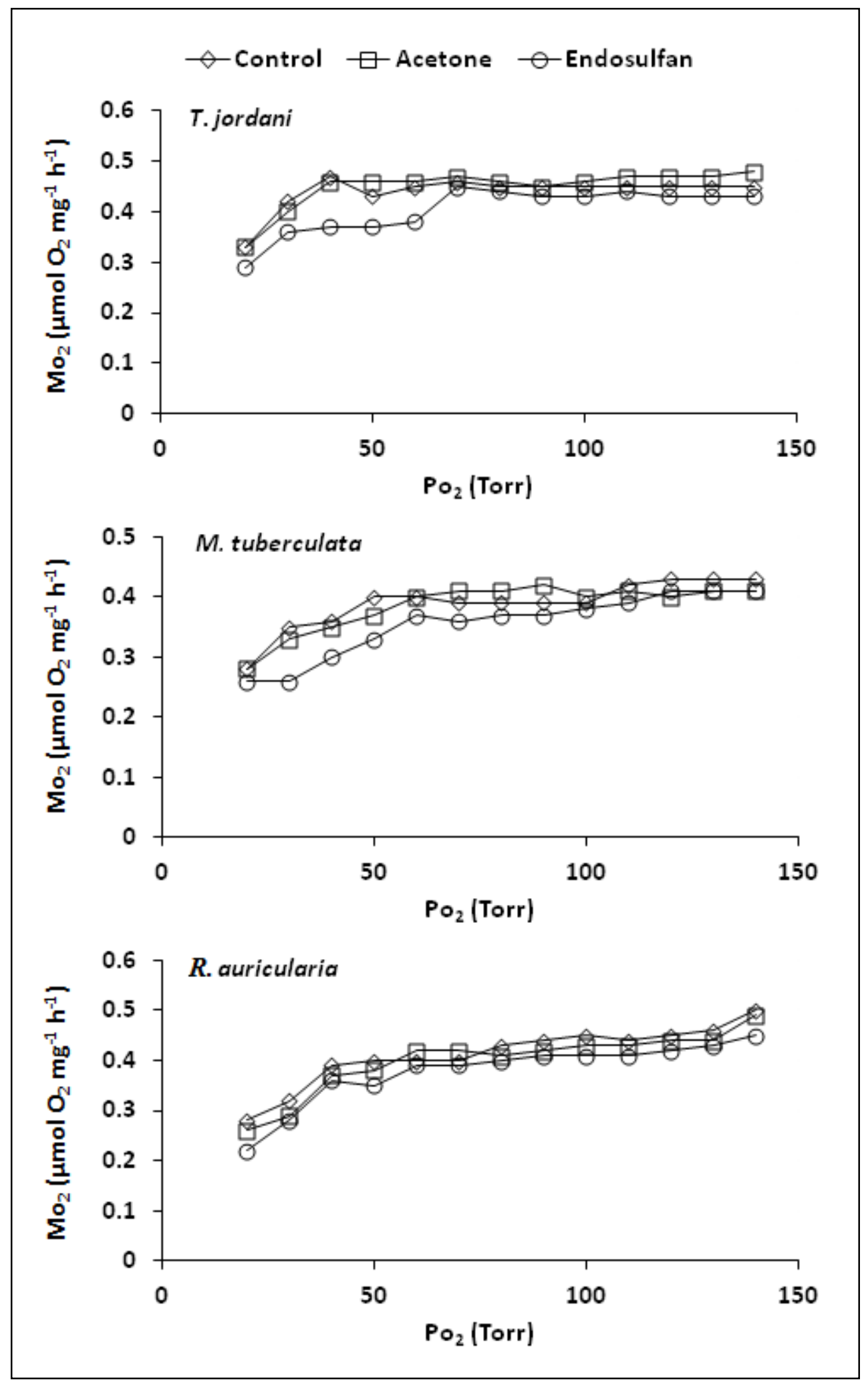

Fig. (2): Effect of endosulfan on the relationship between Mo2 and Po2 for Shatt Al-Arab river snails. 


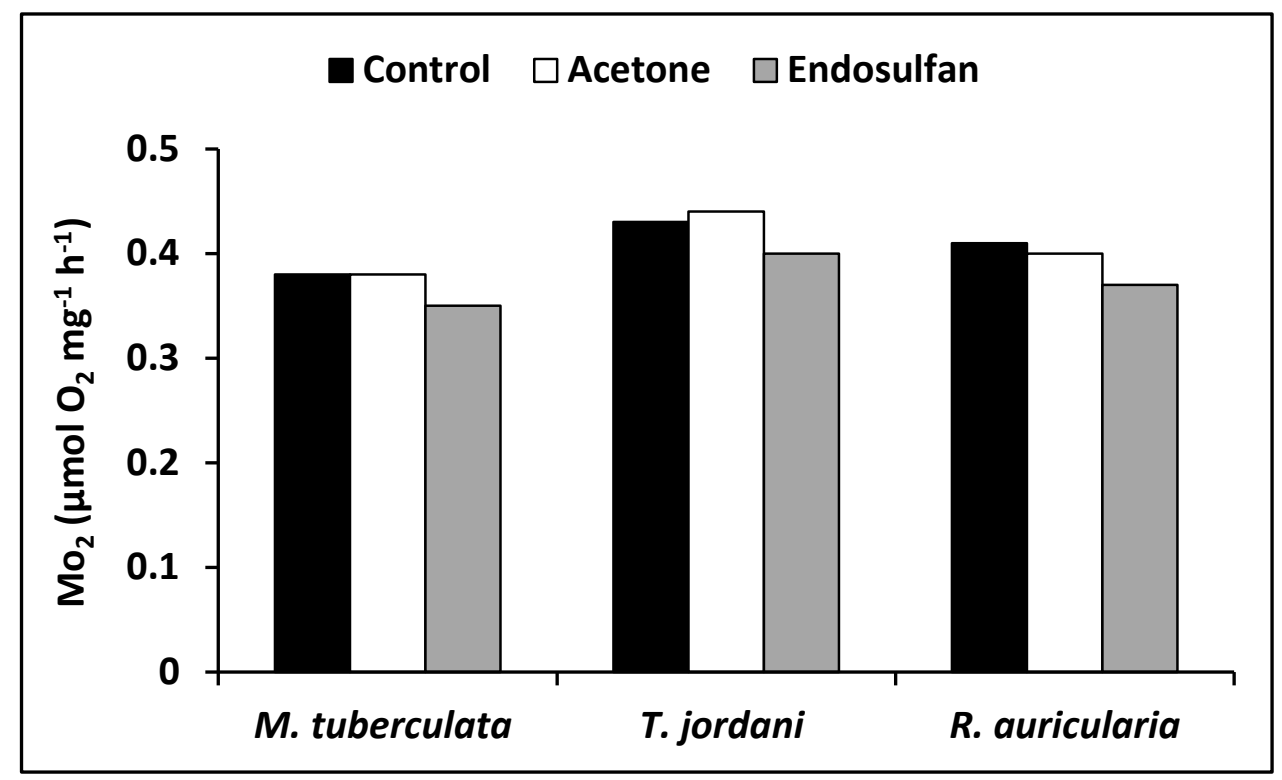

Fig. (3): The mean values of Moz of Shatt Al-Arab river snails for each treatment.

There was no prior study of endosulfan toxicity on snail species. As comparison with other species subjected to pesticide. Jayaraj et al. (2016) reported the acute toxicity of many organochlorine pesticides to many living organisms. The researchers found that organisms were highly sensitive to these pesticides after different periods of exposure. WHO (1984) documented that $24 \mathrm{hr} \mathrm{LC}_{50}$ was 0.30 mg. $1^{-1}$ for Procambarus clarkia subjected to pesticide endosulfan. Nebeker $e t$ al. (1983) found that $96 \mathrm{hr} \mathrm{LC}_{50}$ was 0.34 mg. $\mathrm{l}^{-1}$ of Daphnia magna effected by endosulfan, while Ferrando et al. (1992), which also worked on D. magna, reported that the $24 \mathrm{hr} \mathrm{LC} \mathrm{LC}_{50}$ of the species was 0.62 mg. $\mathrm{l}^{-1}$ and the $48 \mathrm{hr} \mathrm{LC}_{50}$ was $0.487 \mathrm{mg} . \mathrm{l}^{-1}$ as found by (Barry et al.,1995).

The values of $24 \mathrm{hr} \mathrm{LC}_{50}$ for $T$. jordani and R.auricularia were less than those reported by Fernández-Casalderrey et al. (1993) of Brachioms plicatilis $24 \mathrm{~h} \mathrm{LC} 50$ of $5.60 \mathrm{mg} . \mathrm{l}^{-1}$ and B. calyciflorus $24 \mathrm{hr} \mathrm{LC} \mathrm{L}_{50}$ of $5.15 \mathrm{mg} . \mathrm{l}^{-1}$ subjected to pesticide endosulfan. The data of the current study display that $T$. jordani and
R.auricularia are more sensitive to endosulfan than $B$. plicatilis and $B$. calyciflorus. Whereas, M. tuberculata is lower susceptible to endosulfan than the two species mentioned above .

M. tuberculata, T. jordani and R.auricularia are common snails in Shatt AlArab river. Therefore, the use of different species of snails with different sensitivity to the same toxic substance in the toxicity test could be worthy in assessing the toxicity of toxicants in the river.

Under normoxic conditions, the $\mathrm{Mo}_{2}$ for each species of snail were not influenced by exposure to $24 \mathrm{hr}$ of pesticide endosulfan . In addition to, $\mathrm{Mo}_{2}$ was not influenced by the acetone employed. A same impact (no $\mathrm{Mo}_{2}$ was observed) was registered among else aquatic animals after subjected to toxic compound (Shivakumar \& David, 2004; Vutukuru 2005; Anita Susan et al., 2010; Chebbi \& David, 2010).

All species of snails were able to maintain $\mathrm{Mo}_{2}$ independent of $\mathrm{Po}_{2}$, through a broad scope of oxygen tenseness. The critical values 
of $\mathrm{Po}_{2}(\mathrm{Pc})$ were analogous among snails species and were permanently increased when snails were subjected to $24 \mathrm{hr} \mathrm{LC}_{50}$ for pesticide (endosulfan), suggesting that their capability to preserve independence of respiratory through hypoxia decreased after subjected to endosulfan.

In general, the aquatic animals respiratory responses to toxic compound are extremely changeable. The low or high response for oxygen consuming can be imputed not only to variation in species but likewise for concentration of toxic substance (Chebbi \& David, 2010). Roberts (1972) reported that pesticide endosulfan reduces the oxygen consumption rate in Pecten maximus and Mytius edulis (bivalves). WHO (1984) documented an high respiration rate of the gill in $P$. clarkia (crayfish) after subject to pesticide endosulfan $\left(96 \mathrm{hr} \mathrm{LC}_{50}\right)$ at $22{ }^{\circ} \mathrm{C}$, while lindane pesticide generated a high respiratory rate only at high concentrations. The investigation of Sharp et al. (1979) showed that the oxygen consumption for Crancon franciscorum lowered with increased kelthane pesticide concentration. Whereas, Anderson (1971) reported that low grades of DDT pesticide led to reduce in the standard metabolic of salmon,(Salmon salar) while high concentrations of DDT (30-75) $\mu$ $\mathrm{L}^{-1}$ enhanced the rate of fish standard metabolic.

\section{Conclusion}

The $24 \mathrm{hr} \mathrm{LC}_{50}$ indicated that the $M$. tuberculata was more resistant, while R.auricularia and $T$. jordani were more sensitive to endosulfan. No $24 \mathrm{hr} \mathrm{LC}_{50}$ effect of endosulfan was observed on $\mathrm{Mo}_{2}$. This can be attributed to the truth that the pesticide (endosulfan) concentrations utilized weren't sufficient for simulate the rate of respiration in different species of snails. More acquaintance is required to determine the dose-impact relations of toxic substances on snails respiration.

\section{Acknowledgement}

The authors wish to acknowledge the Department of Community Health Technology, College of Health and Medical Technology in Basrah, Southern Technical University for providing the laboratory facilities.

Conflict of interest: The authors declare that they have no conflict of interest.

Ethical approval: all applicable national and international guidelines for the care and use of animals were followed.

\section{References}

Ahmed, F.; Aziz, M.A.; Alam, M.J.; Hakim, M.A.; Khan, M.A.S. \& Rahman, M.A. (2015). Impact on aquatic environment for water pollution in the Vahirab river. IJES, 4(8): 56-62.

Alexis, K.; Jean-Claude, C.; Carole, D.; Le Bruhec, J.; Philippe N. \& Berengere, H. (2017). Respiration of bivalves from three different deep-sea areas: cold seeps, hydrothermal vents and organic carbonrich sediments. Deep Sea Research Part II, 142: 233-243.

Anderson, J.M. (1971). Sublethal effects and changes in ecosystems-assessment of the effects of pollutants on physiology and behavior. Proc. Roy. Soc. Lond., Ser B 177: 307-320.

Anita Susan, T.; Sobha, K. \& Tilak, K.S. (2010). A study on acute toxicity, oxygen consumption and behavioral changes in the three major carps, Labeo rohita (ham), Catla catla (ham) and Cirrhinus mrigala 


\section{Al-Salman et al. / Basrah J. Agric. Sci., 32 (Special Issue): 323-331, 2019}

(ham) exposed to Fenvalerate. Bioresearch Bull., 1: 35-43.

Archambault, J.M. \& Cope, W.G. (2016). Life stage sensitivity of a freshwater snail to herbicides used in invasive aquatic weed control. FMBC, 19: 69-79.

Barry, M.J.; Logan, D.C.; Ahokas, J.T. \& Holdway, D.A. (1995). An effect of algal food concentration on toxicity of two agricultural pesticides to Daphnia carinata. Ecotox. Environ. Safe., 32: 273-279.

Bhuiyan, A.; Mokhtar, M.B.; Toriman, M.E.; Gasim, M.B.; Ta, G.C.; Elfithri, R. \& Razman, M.R. (2013). The environmental risk and water pollution: A review from the river basins around the world. AEJSA, 7(2): 126-136.

Bruce, P. \& Bruce A. (2017). Practical statistics for data scientists: 50 Essential concept. Oreilly and Associates Inc., 298 pp.

Burridge, L. (2013). A review of potential environmental risks associated with the use of pesticides to treat Atlantic salmon against infestations of sea lice in southwest New Brunswick, Canada. DFO Canadian Science Advisory Secretariat Research Document, 2013/050. iv + 25 pp.

Chebbi, S.G. \& David, M. (2010). Respiratory responses and behavioral anomalies of the carp Cyprinus carpio under quinalphos intoxication in sublethal doses. ScienceAsia, 36: 12-17.

Farid, W.A.A. (2007). The use of some species of molluscs of the Shatt Al-Arab river in the toxicity tests, bioaccumulation and monitoring of oil pollution. Ph.D. Thesis, Coll. Sci. Univ. Basrah:198pp.

Fernández-Casalderrey, F.; Ferrando, F.M. \& Andreu-Moliner, E. (1993). Effect of the insecticide methyl parathion on filtration and ingestion rates of Brachionus calyciflorus and Daphnia magna. Sci. Total Environ., 134(2): 867-876.

Ferrando, M.D.; Andreu-Moliner, E. \& Fernandez-Casalderrey, A. (1992). Relative sensitivity of Daphnia magna and Brachionus calyciflorus to five pesticides. J. Environ. Sci. Heal. Part B, 27: 511-522.

Finnegan, M.C.; Baxter, L.R.; Maul, J.D.; Hanson, M.L. \& Hoekstra, P.F. (2017). Comprehensive characterization of the acute and chronic toxicity of the neonicotinoid insecticide thiamethoxam to suite of aquatic primary producers, invertebrates, and fish, Environ. Toxicol. Chem., 9999: 1-11.

Hose, G.C. \& Van den Brink, P.J. (2004). Confirming the species-sensitivity distribution concept for endosulfan using laboratory, mesocosm, and field data. Arch Environ. Contam. Toxicol., 47: 511-520.

Huang, Y.Y. (2001). Pollution Ecology of Inland Water. 112-13, Beijing, Science Press: 267pp.

Jadhav, M.R.; Bawane, V.S. \& Jadhav, B.N. (2012). Effect of rate of oxygen consumption in freshwater bivalve mollusk, Lamellidens corrianus from Godavari river at Kaigaon: In the effect of cerebralectomy and injection of cerebral extract during Summer. Trends Fish. Res., 1(1): 34-37.

Jayaraj, R.; Megha, P. \& Sreedev, P. (2016). Organochlorine pesticides, their toxic effects on living organisms and their fate in the environment. Interdiscip. Toxicol., 9(3-4): 90-100.

Kamble V.S. \& Shinde, R.A. (2012). Impact of organochlorine pesticide on oxygen 
Al-Salman et al. / Basrah J. Agric. Sci., 32 (Special Issue): 323-331, 2019

consumption in the freshwater bivalve mollusk Lamellidens Corrianus. Res. J. Pharm. Biol. Chem. Sci., 3(2): 607613.

Mane, B.U.; Kamble, V.S. \& Rao, K.R. (2012). Effect of acute toxicity of organochlorine pesticide on respiration in lamellibranch mollusc Lamellidens corrianus during winter season. Am. Eurasian J. Toxicol. Sci., 4(3): 151-153.

Mateo-Sagasta, J. \& Burke, J. (2010). Agriculture and water quality interactions: a global overview. SOLAW Background Thematic Report-TR08. Rome, Food and Agriculture Organization of the United Nations (FAO): 46pp.

Nebeker, A.V.; McCrady, J.K.; Mishar, R. \& McAuliffe, C.K. (1983). Relative sensitivity of Daphnia magna, rainbow trout and fathead minnow to endosulfan. Environ. Toxicol. Chem., 1: 69-72.

Roberts, D. (1972). The assimilation and chronic effects of sublethal concentration of endosulfan on condition and spawning in the common mussel Mytillus edulis. Mar. Biol., 16: 119-125.

Schafer, R.B.; Caquet, T.; Siimes, K.; Mueller, R.; Lagadic, L. \& Liess, M. (2007). Effects of pesticides on community structure and ecosystem functions in agricultural headwater streams of three biogeographical regions in Europe. Sci. Total Environ., 382: 272-285.

Schreinemachers, P. \& Tipraqsa, P. (2012). Agricultural pesticides and land use intensification in high, middle and low income countries. Food Policy, 37: 616626.
Sharp, J.W.; Sitts, R.M. \& Knight, A.W. (1979). Effects of Kelthane on the estuarine shrimp Crangon franciscorum (Stimpson). Mar. Biol., 50: 367-374.

Shivakumar, R. \& David, M. (2004). Toxicity of endosulfan to the freshwater fish, Cyprinus carpio. Indian J. Ecol., 31: 2729.

USEPA (U.S. Environmental Protection Agency) (2002). Methods for measuring the acute toxicity of effluent and receiving waters to freshwater and marine organisms. $5^{\text {th }}$ ed, October 2002. EPA-821R-02-012. U.S. Environmental Protection Agency, Washington, D.C.; 266pp.

WHO (World Health Organization) (1984). Endosulfan. International Programme on Chemical Safety. Environmental Health Criteria. Vol. 40. Geneva, 62pp.

Varó, I.; Taylor, A.C. \& Amat, F. (1993). Comparsion of two methods measuring the rates of oxygen consumption of small aquatic animals (Artemia). Camp. Biochem. Physiol, 106A (3): 551-555.

Vutukuru, S.S. (2005). Acute effects of hexavalent chromium on survival, oxygen consumption, hematological parameters and some biochemical profiles of the Indian major carp, Labeo rohita. IJER, 2(3): 456-462.

Xu, D. \& Liu, G. (2014). The effects of DDT on the feeding, respiration, survival, and reproduction of Sinocalanus tenellus (Copepoda: Calanoida). Acta Oceanol. Sin., 33(9): 133-138.

Zimmer, E.I.; Ducrot, V.; Jager, T.; Koene, J.; Lagadic, L. \& Kooijman, S.A.L.M. (2014). Metabolic acceleration in the pond snail, Lymnaea stagnalis. J. Sea Res., 94: 84-91. 